\title{
The evaluation of the technical condition of engines following intermittent emission tests carried out by vehicle inspection stations
}

\begin{abstract}
The paper presents an analysis of the engine technical condition of vehicles subjected to intermittent vehicle inspections at inspection stations. The investigations were realized on the equipment compliant with the relevant legal regulations. The obtained results allowed statistical conclusions related to the emission level in individual age groups of gasoline and diesel engines. None of the diesel engines exceeded the exhaust opacity limits specified in the legislation. In gasoline engines the lowest concentrations were observed in the group of vehicles below 7 years of operation. From the total number of tested gasoline vehicles 7 exceeded the admissible limits (they were assigned for retesting).
\end{abstract}

Key words: combustion engine, exhaust gases, tests

\section{Ocena stanu technicznego silników na podstawie okresowych badań emisyjnych w SKP}

W artykule przedstawiono analizę stanu technicznego silników pojazdów poddawanych okresowym badaniom technicznym $w$ Stacji Kontroli Pojazdów. Tok badawczy przeprowadzono, opierając się na wyposażeniu zgodnym z unormowaniami prawnymi odnośnie do przedmiotowej kwestii. Uzyskane wyniki pozwolity na wnioskowanie statystyczne o emisyjności w poszczególnych grupach wiekowych silników o zapłonie iskrowym i samoczynnym. Wszystkie badane samochody z silnikami ZS nie przekraczały ustawowego limitu w zakresie zadymienia spalin. Wśród samochodów z silnikami ZI najniższe stężenia stwierdzono w grupie poniżej 7 lat eksploatacji. Z ogólnej liczby przebadanych samochodów z silnikami ZI, siedem przekroczyło dopuszczalne limity (skierowano je do powtórnego badania).

Słowa kluczowe: silnik spalinowy, spaliny, badania

\section{Introduction}

The evaluation of the technical condition of an object (here: vehicle engine) is realized through comparison of the diagnostic model (according to the diagnostic principles) based on given diagnostics of a vehicle with the reference models and the models of all previous vehicle diagnostics. A technical condition is rarely reflected on a single model and usually in order to determine such a technical condition sets of diagnostic models are compared.

An important element of the diagnostic process is predicting of the engine technical condition. Further operation of the object and its maintenance intervals are dependent on the result of such predictions [2].

Diagnostics follows a decision made by the owner (user) of a vehicle based on the observed malfunctions during operation or is a result of an inspection requirement.

Emission-related malfunctions or some of the other malfunctions that may have impact on the traffic safety do not generate visible symptoms or these symptoms appear only in critical situations. For this reason in all developed countries there is a requirement of periodical technical inspections during which the exhaust emission level is checked [3].

According to the legal regulations the vehicle owner is required to have the vehicle periodically checked at an inspection station. Periodical and supplementary inspections are performed by the first priority and regional inspection stations at the expense of the vehicle owner or vehicle user.

\section{Wprowadzenie}

Ocena stanu technicznego obiektu (tu: silnika pojazdu) realizowana jest przez porównywanie, zgodnie z zasadami diagnostyki, modelu diagnostycznego $\mathrm{z}$ aktualnego diagnozowania z modelami wzorcowymi i z modelami ze wszystkich poprzednich diagnoz. Stan techniczny rzadko daje się odwzorować na jednym modelu i zazwyczaj w celu jego określenia porównywane są zbiory modeli diagnostycznych.

Ważnym elementem procesu diagnozowania jest prognozowanie stanu technicznego. Od wyniku prognozowania zależy dalsze użytkowanie oraz ustalenie następnych obsług obiektu [2].

Diagnostyka jest efektem decyzji podjętej przez właściciela (posiadacza) pojazdu na podstawie zauważonych podczas eksploatacji objawów uszkodzeń lub obowiązku okresowej kontroli.

Uszkodzenia emisyjne oraz niektóre uszkodzenia wpływające na bezpieczeństwo ruchu nie generują zauważalnych dla kierowcy symptomów lub symptomy te pojawiają się w sytuacjach krytycznych. $\mathrm{Z}$ tego powodu we wszystkich rozwiniętych krajach istnieje obowiązek okresowych badań technicznych pojazdów, podczas których sprawdzany jest poziom emisji związków toksycznych [3].

Zgodnie z prawem obowiązek przedstawienia pojazdu do badania technicznego spoczywa na właścicielu. Okresowe i dodatkowe badania techniczne wykonywane sa przez podstawowe i okręgowe stacje kontroli pojazdów na koszt właściciela lub użytkownika pojazdu. 


\section{Research objects and methodology}

In the course of the investigations related to the measurement of the level of exhaust emissions and the $\lambda$ coefficient of vehicles fitted with gasoline engines these engines were divided into three variant groups according to the period of their operation as specified by the legislation:

- group I/ZI (13 units) - vehicles registered from 1 May 2004,

- group II/ZI (38 units) - vehicles registered from 1 July 1995 to 30 April 2004,

- group III/ZI (8 units) - vehicles registered till 30 June 1995.

Following the measurement of the exhaust gas opacity generated by diesel engines these were divided into three simple groups:

- group I D (13 units) - vehicles registered till 31 December 2000 ,

- group II D (18 units) - vehicles registered from 1 January 2001 to 31 December 2003,

- group III D (19 units) - vehicles registered from 1 January 2004

The checkup/testing methods of the vehicle technical condition are specified by the regulation of the Minister of Infrastructure dated 18 September 2009 (scope and manner of realization of technical inspections along with specimens of documents used with these inspections (Journal of Laws dated 2009, no. 155, item 1232) and conditioned by the type of testing equipment at the inspection station. The order of actions performed by the diagnostic technician while performing the tests at the station is closely related to the type of test and the location of the measuring equipment on the test stand $[4-9,12]$.

The tests were performed in one of the Podlasie Regional Inspection Stations. The authors utilized the equipment of that station (Fig. 1).

The levels of the admissible emissions and excess air coefficient $\lambda$ are specified in appendix 2 to the regulation of the Minister of Infrastructure dated 31 December 2002 on the technical condition of vehicles and the extent of the required equipment (Journal of Laws, dated 2003, no. 32, item 262 as amended).

a)

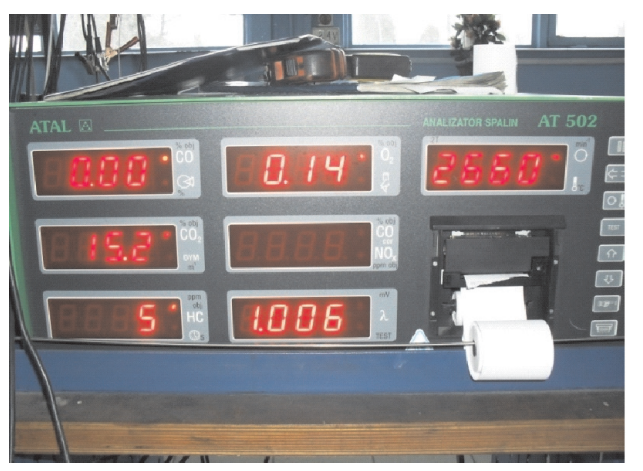

b)
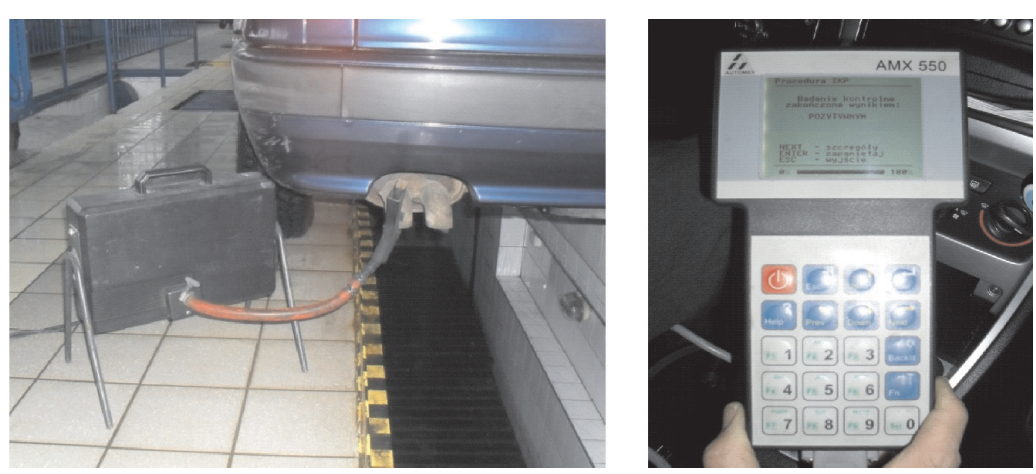

Fig.1. Equipment used for the measurements: a) and b) exhaust gas analyzer and smoke meter ATAL 502/AT, c) AMX 550 scan tool Rys. 1. Wyposażenie wykorzystywane podczas badań: a) i b) zestaw analizator spalin i dymomierz ATAL 502/AT, c) czytnik informacji diagnostycznej AMX 550 
Detailed directions of the measurement of the exhaust emissions from gasoline vehicles during the inspection are specified by Chapter IV of the appendix 1 to Regulation of the Minister of Infrastructure dated 18 September 2009 (Journal of Laws dated 2009, no. 155, item 1232). The directions are dependent on the first registration of the vehicle. In vehicles registered till 30 June 1995 the measurement of the $\mathrm{CO}$ concentration is performed in the exhaust gases at idle speed. In vehicles registered from 1 July 1995 to 30 April 2004 the measurement of the content of CO and HC in the exhaust gases is first done at an elevated engine speed $(2000 \ldots 3000 \mathrm{rpm})$ and then at idle speed. At an elevated engine speed $(2000 \ldots 3000 \mathrm{rpm})$ also the value of the excess air coefficient $\lambda$ is measured. In motor vehicles registered from 1 May 2004 the measurement of the CO concentration and the $\lambda$ value is performed at an elevated engine speed $(2000 \ldots 3000 \mathrm{rpm})$ and then at idle speed the content of CO in the exhaust gas is measured.

The smoke level (opacity) of a diesel vehicle exhaust is specified in $\S 9$, subpar. 1 , item 3 of the regulation of the Minister of Infrastructure dated 31 December 2002 on the technical condition of vehicles and the extent of the required equipment (Journal of Laws, dated 2003, no. 32, item 262 as amended). It cannot exceed $2.5 \mathrm{~m}^{-1}$, in turbocharged engines $3.0 \mathrm{~m}^{-1}$ and in vehicles manufactured after 30 June $2008-1.5$ $\mathrm{m}^{-1}$. The values are expressed in light absorption coefficient $\mathrm{k}$. The table of unit conversion of the Hartrige HRT percentage scale to the units of the $\mathrm{k} \mathrm{m}^{-1}$ coefficient and the way of smoke level measurement during the test are contained in chapter IV of appendix 1 to the regulation of the Minister of Infrastructure dated 18 September 2009 (Journal of Laws dated 2009, no. 155, item 1232)

Each year the number of vehicles fitted with on-board diagnostics OBD II/EOBD grows. The passing of the OBD test during the technical inspection at an inspection station was based on the procedures of the AMX 550 scan tool. The OBD port was located in the place designated by the manufacturer $[1,10]$.

\section{Results and analysis}

The comparison is very general in its nature, as only 116 vehicles have been tested. The calculations were made only for vehicles of the emission level that complied with the legal requirements (109 units). During the tests 7 vehicles did not pass the emission tests and were directed for repair and retesting.

The statistical processings covered [11]: - Arithmetic average:

$$
\overline{\mathrm{x}}=\frac{\mathrm{x}_{1}+\mathrm{x}_{2}+\ldots+\mathrm{x}_{\mathrm{n}}}{\mathrm{n}}
$$

- estimator of standard deviation:

$$
s_{b}=\sqrt{\frac{1}{n-1} \cdot \sum_{i=1}^{n}\left(x_{i}-\bar{x}\right)^{2}}
$$

- median:

$$
\mathrm{M}=\frac{\mathrm{n}+1}{2}
$$

jazdów oraz zakresu ich niezbędnego wyposażenia (Dz. U. z 2003 r., nr 32, poz. 262 z późniejszymi zmianami).

Szczegółowy sposób pomiaru emisji zanieczyszczeń gazowych spalin pojazdów z silnikiem o ZI podczas przeprowadzania badania technicznego określa dział IV załącznika nr 1 do rozporządzenia Ministra Infrastruktury z 18 września 2009 r. (Dz. U. z 2009 r., nr 155, poz. 1232). Jest on ściśle związany z datą pierwszej rejestracji pojazdu. W pojazdach samochodowych zarejestrowanych do 30 czerwca $1995 \mathrm{r}$. wykonuje się pomiar poziomu zawartości tlenku węgla (CO) w objętości spalin przy prędkości obrotowej biegu jałowego. Dla pojazdów samochodowych zarejestrowanych od 1 lipca 1995 r. do 30 kwietnia 2004 r. pomiar poziomu zawartości tlenku węgla (CO) i poziomu zawartości węglowodorów (HC) w objętości spalin przeprowadza się najpierw przy podwyższonej prędkości obrotowej silnika (2000...3000) obr/min, a następnie przy prędkości obrotowej biegu jałowego. Przy podwyższonej prędkości obrotowej silnika (2000 ...3000) obr/min mierzy się również wartość współczynnika $\lambda$. W pojazdach samochodowych zarejestrowanych od 1 maja 2004 r. wykonuje się pomiar poziomu zawartości CO i wartość współczynnika $\lambda$ przy podwyższonej prędkości obrotowej silnika (2000...3000) obr/min i następnie przy prędkości obrotowej biegu jałowego mierzy się zawartość CO w objętości spalin.

Zadymienie (zaczernienie) spalin pojazdu z silnikiem o ZS określa $\S 9$, ust. 1, pkt 3 rozporządzenia Ministra Infrastruktury z 31 grudnia 2002 r. w sprawie warunków technicznych pojazdów oraz zakresu ich niezbędnego wyposażenia (Dz. U. z 2003 r., nr 32, poz. 262 z późniejszymi zmianami). Nie może ono przekraczać $2,5 \mathrm{~m}^{-1}$, w silnikach $\mathrm{z}$ turbodoładowaniem $3,0 \mathrm{~m}^{-1}$, a w pojazdach wyprodukowanych po 30 czerwca $2008 \mathrm{r}$. $-1,5 \mathrm{~m}^{-1}$. Wyrażone jest $\mathrm{w}$ postaci współczynnika pochłaniania światła k. Tabela zamiany jednostek skali procentowej Hartrige'a HRT na jednostki współczynnika $\mathrm{k} \mathrm{m}^{-1}$ i sposób pomiaru zadymienia spalin pojazdów podczas przeprowadzania badania technicznego zawarte są w dziale IV załącznika nr 1 do rozporządzenia Ministra Infrastruktury z 18 września 2009 r. (Dz. U. z 2009 r., nr 155, poz.1232).

Z każdym rokiem zwiększa się liczba pojazdów wyposażonych w pokładowe systemy diagnostyczne OBD II/EOBD. Ocena przejścia przez system OBD z wynikiem pozytywnym podczas kontroli w SKP bazowała na procedurach opartych na czytniku AMX 550. Obecność gniazda diagnostycznego była w miejscu przewidzianym przez producenta $[1,10]$.

\section{Wyniki badań i ich analiza}

Porównanie ma charakter poglądowy, ponieważ badania przeprowadzono tylko dla 116 pojazdów. Obliczenia wykonano wyłącznie dla pojazdów o emisji zanieczyszczeń na poziomie zgodnym z unormowaniami prawnymi (109 sztuk). Podczas badań wyeliminowano 7 pojazdów niesprawnych emisyjnie, które wymagały naprawy i powtórnego badania.

Obróbka statystyczna objęła wyznaczenie [11]:

- średniej arytmetycznej - wzór (1),

- estymatora odchylenia standardowego (2), 
- sample variance:

$$
s^{2}=\frac{1}{n} \cdot \sum_{i=1}^{n}\left(x_{i}-\bar{x}\right)^{2}
$$

- standard deviation:

- kurtosis:

$$
\mathrm{s}_{\mathrm{o}}=\sqrt{\mathrm{s}^{2}}
$$

$$
\begin{aligned}
K= & \left\{\frac{n \cdot(n+1)}{(n-1) \cdot(n-2) \cdot(n-3)} \cdot \sum_{i=1}^{n}\left(\frac{x_{1}-\bar{x}}{s}\right)^{4}\right\} \\
& -\frac{3 \cdot(n-1)^{2}}{(n-2) \cdot(n-3)}
\end{aligned}
$$

- bias:

$$
A_{d}=\frac{n}{(n-1) \cdot(n-2)} \cdot \sum_{i=1}^{n}\left(\frac{x_{1}-\bar{x}}{s}\right)^{3}
$$

Moreover, the following have been determined: the range, the minimum, the maximum, the sum, the counter and confidence level that marks the probability that the result of the measurement falls in the range of the bounded interval limited by the extended uncertainty of the measurement. The results
- mediany (3),

- wariancji próbki (4),

- odchylenia standardowego (5),

$-\operatorname{kurtozy}(6)$,

- skośności (7).

Ponadto wyznaczono: zakres, minimum, maksimum, sumę, licznik, poziom ufności, który oznacza prawdopodobieństwo, że wynik pomiaru zawiera się $\mathrm{w}$ przedziale domkniętym ograniczonym niepewnością rozszerzoną pomiaru. Nie eliminowano wyników na podstawie testu Dixona i Grubbsa z uwagi na różnorodność badanych pojazdów w grupach.

Ze względu na obszerność wyników pomiarów, na rys. 2 i 3 przedstawiono w postaci wykresów słupkowych zestawienia wyznaczonych wartości poszczególnych składników spalin w grupach pojazdów. Wyniki obliczeń statystycznych wykonanych z wykorzystaniem procedur programu Excel przedstawiono $\mathrm{w}$ tab. 1 i 2 . Wnioskowanie o zgodności rozkładów z rozkładem normalnym oparto na wartościach skośności i kurtozy.

Z 95-procentowym prawdopodobieństwem stwierdzono, że w grupie I/ZI wartość średnia poziomu emisji CO przy

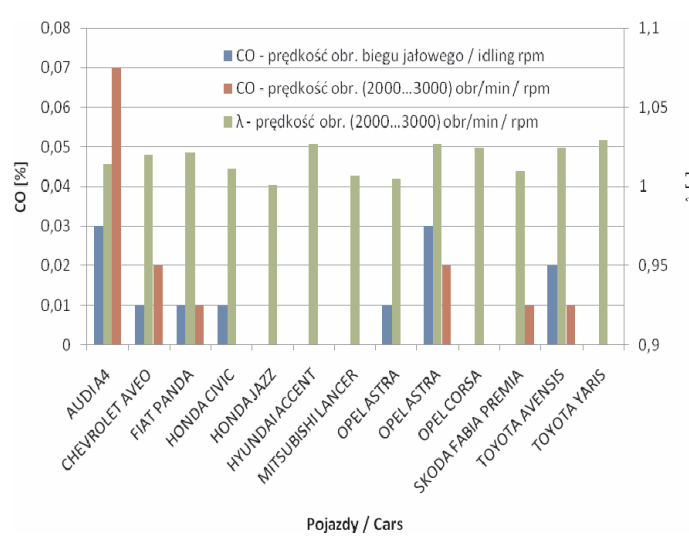

c)

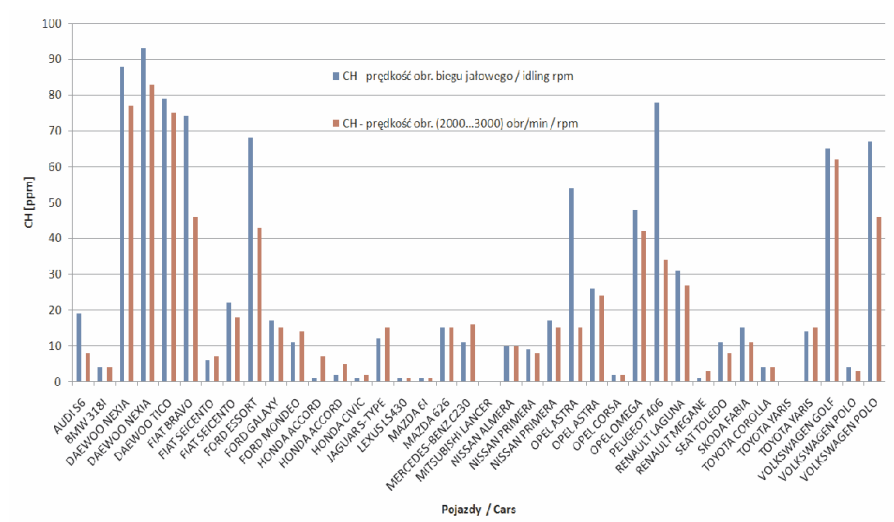

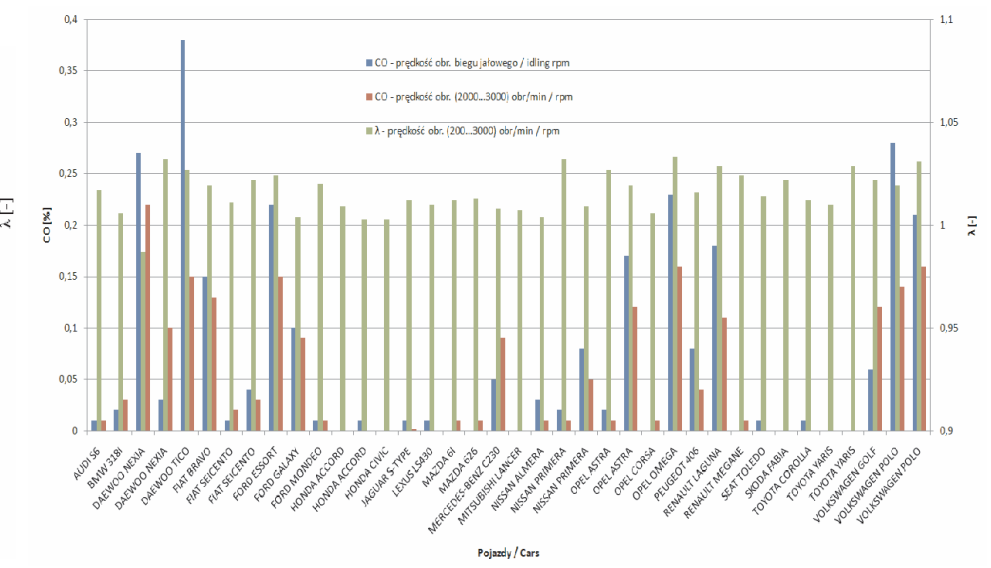

d)

Fig. 2. The determined characteristic values while testing the gasoline engines: a) $\mathrm{CO}$ and $\lambda$ in group I/ZI, b) $\mathrm{CO}$ and $\lambda$ in group II/ZI, c) $\mathrm{HC}$ in group II/ZI, d) - CO in group III/ZI

Rys. 2. Wyznaczone wartości charakterystyczne przy badaniu silników o ZI: a) CO i $\lambda$ w grupie I/ZI, b) CO i $\lambda$ w grupie II/ZI, c) HC w grupie II/ZI, d) $C O w$ grupie III/ZI 
Table 1. The results of the calculations for gasoline engine groups

Tabela 1. Wyniki obliczeń dla grup silników o zapłonie iskrowym

\begin{tabular}{|c|c|c|c|c|c|c|c|c|c|}
\hline \multirow[t]{2}{*}{ Parameter } & \multicolumn{3}{|c|}{$\mathrm{I} / \mathrm{ZI}$} & \multicolumn{5}{|c|}{ II/ZI } & \multirow{2}{*}{$\begin{array}{c}\mathrm{III} / \mathrm{ZI} \\
\mathrm{CO}[\%]\end{array}$} \\
\hline & - CO [\%] & a $\mathrm{CO}[\%]$ & $=\lambda[-]$ & - $\mathrm{CO}[\%]$ & - $\mathrm{CO}[\%]$ & $=\lambda[-]$ & a $\mathrm{HC}[\mathrm{ppm}]$ & - $\mathrm{HC}[\mathrm{ppm}]$ & \\
\hline Average/średnia & 0.009231 & 0.010769 & 1.016923 & 0.071053 & 0.052684 & 1.015895 & 25.81579 & 20.55263 & 1.34 \\
\hline $\begin{array}{l}\text { Standard error/btad } \\
\text { standadrowy }\end{array}$ & 0.003093 & 0.005366 & 0.002608 & 0.016164 & 0.010326 & 0.001677 & 4.764564 & 3.701466 & 0.347327 \\
\hline Median/mediana & 0.01 & 0 & 1.02 & 0.02 & 0.01 & 1.015 & 13 & 14.5 & 0.955 \\
\hline $\begin{array}{l}\text { Standard deviation/od- } \\
\text { chylenie standardowe }\end{array}$ & 0.011152 & 0.019348 & 0.009403 & 0.099642 & 0.063657 & 0.010337 & 29.37075 & 22.81737 & 0.982388 \\
\hline $\begin{array}{l}\text { Sample variance/warian- } \\
\text { cja próbki }\end{array}$ & 0.000124 & 0.000374 & $8.84 \mathrm{E}-05$ & 0.009929 & 0.004052 & 0.000107 & 862.6408 & 520.6323 & 0.965086 \\
\hline Kurtosis/kurtoza & -0.10114 & 8.288706 & -1.3683 & 1.498914 & -0.35911 & 0.095418 & -0.26689 & 1.419081 & -0.74068 \\
\hline Bias/skośność & 1.026154 & 2.72789 & -0.31515 & 1.536482 & 0.971311 & -0.26726 & 1.106688 & 1.512364 & 0.882428 \\
\hline Range/zakres & 0.03 & 0.07 & 0.028 & 0.38 & 0.22 & 0.046 & 93 & 83 & 2.65 \\
\hline Minimum & 0 & 0 & 1.001 & 0 & 0 & 0.987 & 0 & 0 & 0.33 \\
\hline Maximum & 0.03 & 0.07 & 1.029 & 0.38 & 0.22 & 1.033 & 93 & 83 & 2.98 \\
\hline Sum/suma & 0.12 & 0.14 & 13.22 & 2.7 & 2.002 & 38.604 & 981 & 781 & 10.72 \\
\hline Counter/licznik & 13 & 13 & 13 & 38 & 38 & 38 & 38 & 38 & 8 \\
\hline $\begin{array}{l}\text { Confidence level } \\
(95.0 \%) / \text { poziom ufności }\end{array}$ & 0.006739 & 0.011692 & 0.005682 & 0.032752 & 0.020923 & 0.003398 & 9.653924 & 7.499882 & 0.821297 \\
\hline
\end{tabular}

were not eliminated based on the Dixon and Grubbs test because of the wide range of vehicles tested in the groups.

Due to the size of the test results Figure 2 and 3 in the form of bar graphs shows the determined values of individual exhaust gas components in the vehicle groups. The results of the statistical calculations performed with the use of the Excel procedures have been presented in Table 1 and 2 . The conclusions as to the conformity of the distributions with the normal distribution were based on the values of bias and kurtosis.

With a $95 \%$ certainty it has been observed that in group $\mathrm{I} / \mathrm{ZI}$ the average value of the $\mathrm{CO}$ emission at idle speed was $(0.009231 \pm 0.006739) \%$ (Tab. 1) and the average value of the CO emission at elevated engine speeds $-(0.010769$ $\pm 0.011692) \%$. The average value of the $\lambda$ coefficient was $(1.016923 \pm 0.005682)$. In the first case the standard error was $0.003093 \%$, in the second case $0.005366 \%$ and in the third case 0.002608 . The negative value of kurtosis at the emission level of CO at idle $(-0.10114)$ and the $\lambda$ coefficient $(-1.3683)$ confirm that there is a varied flattening of the distributions and the positive value (8.288706) for the emission level of $\mathrm{CO}$ at elevated engine speeds denotes the distribution of very high verticality. In both cases of the emission level of CO the positive bias (1.026154 and 2.72789) determines the distribution with the asymmetry extending towards higher values and the negative bias $(-0.31515)$ and the $\lambda$ coefficient determines the distribution towards lower values.

In group II/ZI the average value of the emission level of $\mathrm{CO}$ at idle speed was $(0.071053 \pm 0.032752) \%$, the average value of the emission level of $\mathrm{CO}$ at an elevated engine speed was $(0.052684 \pm 0.020923) \%$ and the average value of the $\lambda$ coefficient was $1.015895 \pm 0.003398$ respectively. In the first case the standard error was $0.016164 \%$, in the second case $0.010326 \%$ and in the third case 0.001677 . The positive value prędkości obrotowej biegu jałowego wyniosła $(0,009231$ $\pm 0,006739$ )\% (tab. 1), a wartość średnia poziomu emisji CO przy podwyższonych prędkościach obrotowych $-(0,010769$ $\pm 0,011692) \%$. Wartość średnia współczynnika $\lambda$ wyniosła $(1,016923 \pm 0,005682)$. W pierwszym przypadku błąd standardowy wyniósł 0,003093\%, w drugim 0,005366\%, a w trzecim 0,002608 . Wartość ujemna kurtozy przy poziomie emisji CO na biegu jałowym $(-0,10114)$ i współczynniku $\lambda(-1,3683)$ świadczą o zróżnicowanym spłaszczeniu rozkładów, natomiast wartość dodatnia $(8,288706)$ dla poziomu emisji CO przy podwyższonych prędkościach obrotowych oznacza rozkład o bardzo dużej szczytowości. W obu przypadkach wartości poziomu emisji CO skośność dodatnia (1,026154 i 2,72789) określa rozkład z asymetrią rozciągającą się w kierunku wartości większych, a skośność ujemna $(-0,31515)$ i współczynnika $\lambda$ określa rozkład ku wartościom mniejszym.

Odpowiednio w grupie II/ZI wartość średnia poziomu emisji CO przy prędkości obrotowej biegu jałowego wyniosła $(0,071053 \pm 0,032752) \%$, wartość średnia CO przy prędkości podwyższonej wyniosła $(0,052684 \pm 0,020923) \%$, a wartość średnia $\lambda=1,015895 \pm 0,003398$. W pierwszym przypadku błąd standardowy wyniósł 0,016164\%, w drugim 0,010326\%, w trzecim 0,001677. Wartość dodatnia kurtozy dla poziomu emisji CO na biegu jałowym $(1,498914)$ i współczynnika $\lambda(0,095418)$ uwidacznia wysmuklenia rozkładów, a wartość ujemna $(-0,35268)$ dla poziomu emisji CO przy podwyższonych prędkościach obrotowych oznacza niewielkie spłaszczenie rozkładu. Wartości dodatnie $(1,536482$ i 0,971311$)$ skośności w obu przypadkach poziomu emisji CO skłaniają rozkłady w kierunku wartości większych, a wartość ujemna $(-0,26726)$ skośności określa rozkład w kierunku przeciwnym. W grupie II/ZI wartość 
a)

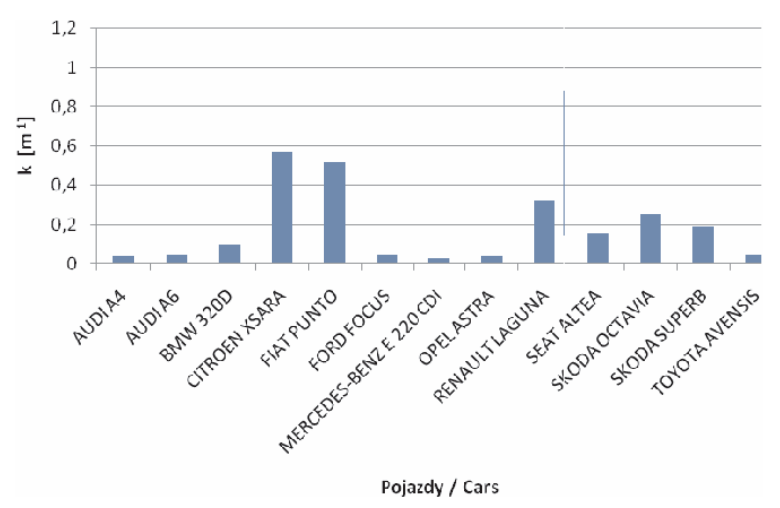

b)

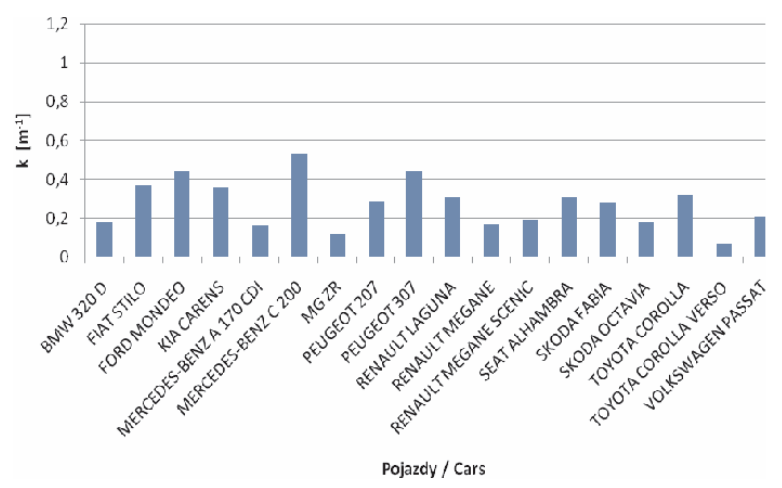

c)

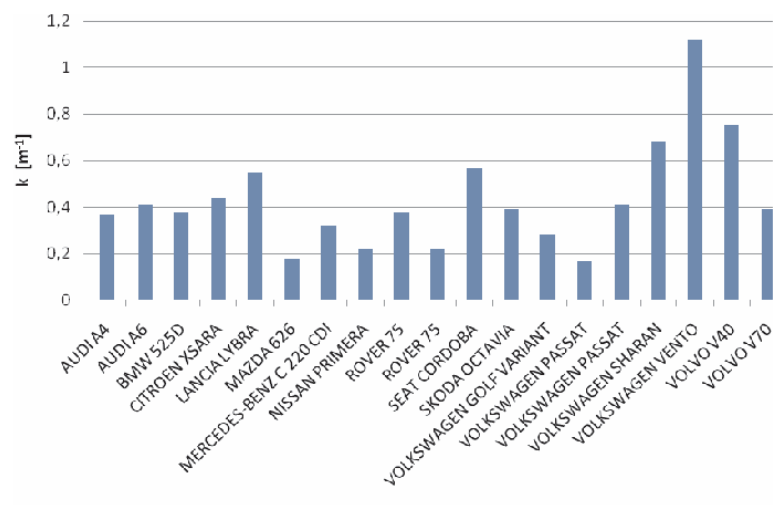

Fig. 3. Opacity level in diesel engines: a) group I/ZS, b) group II/ZS, c) group III/ZS

Rys. 3. Poziom zadymienia spalin silników o ZS: a) grupa I/ZS, b) grupa II/ZS, c) grupa III/ZS

of kurtosis for the emission level of CO at idle (1.498914) and the $\lambda$ coefficient $(0.095418)$ shows a slendering of the distributions and the negative value $(-0.35268)$ for the emission level of $\mathrm{CO}$ at elevated engine speeds denotes a slight flattening of the distribution. Positive values (1.536482 and 0.971311) of the bias in both cases of the $\mathrm{CO}$ emission push the distributions in the direction of higher values and the negative value $(-0.26726)$ of the bias denotes a distribution in the opposite direction. In group II/ZI the average value of the emission of HC średnia poziomu emisji HC przy prędkości obrotowej biegu jałowego wyniosła $(25,81579 \pm 9,653924)$ ppm, a przy podwyższonych prędkościach $(20,55263 \pm 7,499882) \mathrm{ppm}$. W pierwszym przypadku błąd standardowy wyniósł 4,764564 ppm, a w drugim 3,701466 ppm. Wartość ujemna $(-0,26689)$ kurtozy dla poziomu emisji HC na biegu jałowym wskazuje na niewielkie spłaszczenie rozkładu, a w drugim przypadku wartość dodatnia $(1,419081)$ oznacza rozkład o stosunkowo dużym wysmukleniu. W obu przypadkach rozkład skłania się w kierunku wartości większych, ponieważ skośności przyjęły wartości dodatnie $(1,106688$ i 1,512364).

W grupie III/ZI wartość średnia emisji CO wyniosła $(1,34 \pm 0,821297) \%$. Błąd standardowy wyniósł 0,347327\%. Wartość ujemna kurtozy $(-0,74068)$ oznacza rozkład stosunkowo płaski. Skośność dodatnia $(0,882428)$ określa rozkład z asymetrią rozciągającą się w kierunku wartości większych.

Z 95-procentowym prawdopodobieństwem stwierdzono, że wartość średnia poziomu zadymienia spalin w grupie $\mathrm{I} / \mathrm{ZS}$ (tab. 3) wyniosła $(0,153077 \pm 0,096289) \mathrm{m}^{-1}$. Błąd standardowy wyniósł $0,044193 \mathrm{~m}^{-1}$. Wartość dodatnia kurtozy $(2,965431)$ oznacza rozkład o stosunkowo dużej szczytowości. Skośność dodatnia $(1,666971)$ określa rozkład z asymetrią rozciągającą się w kierunku większych wartości.

W grupie II/ZS wartość średnia poziomu zadymienia spalin wyniosła $(0,273889 \pm 0,061526) \mathrm{m}^{-1}$. Błąd standardowy wyniósł 0,029162 $\mathrm{m}^{-1}$. Wartość ujemna kurtozy $(-0,54181)$ świadczy o rozkładzie płaskim. Skośność dodatnia (0,26076) określa rozkład z asymetrią rozciągającą się w kierunku wartości dodatnich.

Odpowiednio w grupie III/ZS wartość średnia poziomu zadymienia spalin wyniosła $(0,433158 \pm 0,110168) \mathrm{m}^{-1}$. Błąd standardowy wyniósł $0,052438 \mathrm{~m}^{-1}$. Wartość dodatnia kurtozy $(3,554066)$ świadczy o dużym wysmukleniu rozkładu. Skośność dodatnia $(1,640071)$ określa rozkład z asymetrią rozciągającą się w kierunku wartości większych.

\section{Porównanie pojazdów w różnych grupach wiekowych}

Celem jest szacunkowe odzwierciedlenie faktycznej różnicy badanych parametrów, która (jak wcześniej obliczono) występuje między poszczególnymi grupami wiekowymi pojazdów.

$\mathrm{Na}$ wykresie (rys. 4) przedstawiono wartości średnie poziomu emisji CO badanych pojazdów z silnikami o zapłonie iskrowym.

Widoczna jest duża różnica poziomu emisji CO pomiędzy poszczególnymi grupami pojazdów. Emisja CO dla pojazdów grupy III, które w ruchu miejskim są często wykorzystywane, dotyczy prędkości obrotowej biegu jałowego silnika.

W sytuacji zadymienia spalin widoczny jest wzrost współczynnika k na niekorzyść pojazdów starszych (rys. 5). W pojazdach $z$ grupy III średnia wartość zadymienia jest prawie 3-krotnie większa niż w grupie I. Widoczna jest korelacja pomiędzy wiekiem pojazdu a wartością zadymienia spalin, podobnie jak w sytuacji emisji CO dla silników o ZI. 
at idle was $(25.81579 \pm 9.653924)$ ppm and at elevated engine speeds $(20.55263 \pm 7.499882)$ ppm. In the first case the standard error was $4.764564 \mathrm{ppm}$ and in the second case it was $3.701466 \mathrm{ppm}$. The negative value of kurtosis $(-0.26689)$ for the $\mathrm{HC}$ emission level $\mathrm{HC}$ at idle indicates a miniscule flattening of the distribution and in the second case the positive value (1.419081) denotes a relatively slendered distribution. In both cases the distribution leans towards higher values as the biases assumed positive values (1.106688 and 1.512364).

In group III/ZI the average value of the emission of $\mathrm{CO}$ was $(1.34 \pm 0.821297) \%$. Standard error was $0.347327 \%$. The negative value of kurtosis $(-0.74068)$ denotes a relatively flat distribution. Positive bias (0.882428) determines the distribution with an asymmetry extending in the direction of higher values.

With a $95 \%$ probability it has been observed that the average value of opacity in group I/ZS (Tab. 3) was $(0.153077$ $\pm 0.096289) \mathrm{m}^{-1}$. The standard error was $0.044193 \mathrm{~m}^{-1}$. The positive value of kurtosis (2.965431) denotes a distribution of relatively high verticality. The positive bias (1.666971) determines a distribution with the asymmetry extending towards higher values.

In group II/ZS the average value of the exhaust opacity was $(0.273889 \pm 0.061526) \mathrm{m}^{-1}$. Standard error was 0.029162 $\mathrm{m}^{-1}$. The negative value of kurtosis $(-0.54181)$ confirms a flat distribution. Positive bias (0.26076) denotes the distribution with the asymmetry extending towards positive values.

In group III/ZS the average value of the exhaust opacity was $(0.433158 \pm 0.110168) \mathrm{m}^{-1}$. Standard error was 0.052438 $\mathrm{m}^{-1}$. The positive value of kurtosis (3.554066) denotes large slendering of the distribution. Positive bias (1.640071) denotes the distribution with the asymmetry extending towards higher values.

\section{A comparison in different age groups}

The objective was an estimate reflection of the actual difference in the tested parameters that (as calculated earlier) occurred among the individual age groups of vehicles.

The graphs (Fig. 4) present the average values of the level of $\mathrm{CO}$ emission from the tested gasoline vehicles.

We can see a difference in the emission of $\mathrm{CO}$ among individual groups. The emission of $\mathrm{CO}$ for group III the vehicles of which are frequently used in city traffic is associated with the idle engine speed.

\section{Conclusions}

59 vehicles were subjected to the measurement of the emission level and the $\lambda$ coefficient. Seven vehicles were
Table 2. Results of the calculations for diesel engine groups

\begin{tabular}{|l|c|c|c|}
\hline \multirow{2}{*}{ Parameter } & \multicolumn{3}{|c|}{ 口 $\mathrm{k}\left[\mathrm{m}^{-1}\right]$} \\
\cline { 2 - 4 } & $\mathrm{I} / \mathrm{ZS}$ & $\mathrm{II} / \mathrm{ZS}$ & $\mathrm{III} / \mathrm{ZS}$ \\
\hline Average/średnia & 0.153077 & 0.273889 & 0.433158 \\
\hline Standard error/błąd standardowy & 0.044193 & 0.029162 & 0.052438 \\
\hline Median/mediana & 0.05 & 0.285 & 0.41 \\
\hline Standard deviation/odchylenie standardowe & 0.159342 & 0.123724 & 0.228572 \\
\hline Sample Variance/wariancja próbki & 0.02539 & 0.015308 & 0.052245 \\
\hline Kurtosis/kurtoza & 2.965431 & -0.47565 & 3.554066 \\
\hline Bias/skośność & 1.666971 & 0.36563 & 1.640071 \\
\hline Range/zakres & 0.54 & 0.46 & 0.95 \\
\hline Minimum & 0.03 & 0.07 & 0.17 \\
\hline Maximum & 0.57 & 0.53 & 1.12 \\
\hline Sum/suma & 1.99 & 4.93 & 8.23 \\
\hline Counter/licznik & 13 & 18 & 19 \\
\hline Confidence level (95.0\%)/poziom ufności & 0.096289 & 0.061526 & 0.110168 \\
\hline
\end{tabular}

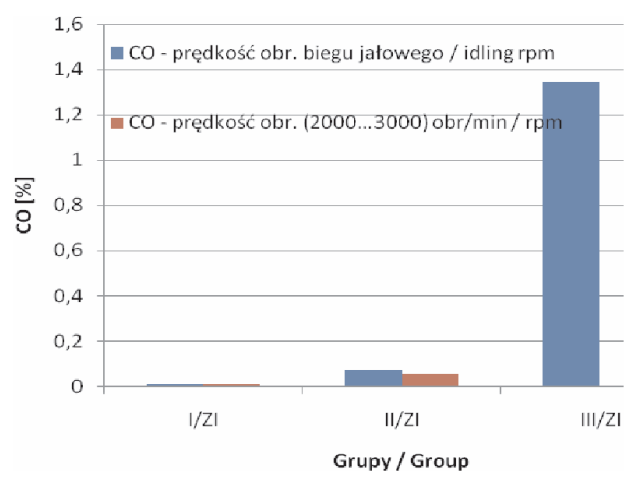

Fig. 4. Average values of the emission level of $\mathrm{CO}$ from the tested gasoline engines

Rys. 4. Wartości średnie poziomu emisji CO pojazdów z silnikami o zaptonie iskrowym

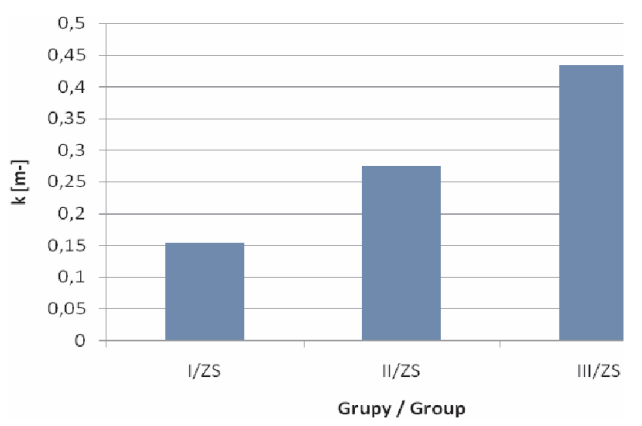

Fig. 5. Average values of the opacity level from vehicles fitted with diesel engines

Rys. 5. Wartości średnie poziomu zadymienia spalin przez pojazdy z silnikami o zapłonie samoczynnym

\section{Podsumowanie}

Pomiarom poziomu zanieczyszczeń gazowych spalin i współczynnika $\lambda$ poddano 59 pojazdów. Wyodrębniono siedem pojazdów niesprawnych emisyjnie. Najbardziej poprawne emisyjnie wyniki pomiarów stwierdzono w 
identified as malfunctioning in terms of emissions. The most satisfactory emission measurement results were observed in vehicles that did not exceed the 7 year period of operation: Honda Jazz, Hyundai Accent, Mitsubishi Lancer, Opel Corsa and two Toyota Yaris vehicles. An exception was an almost 9-year-old Mitsubishi Lancer.

The exhaust opacity tests were performed in 50 vehicles. None of the vehicles exceeded the admissible smoke level. The lowest smoke level was observed in vehicles that did not yet exceed the 6 year period of operation: Audi A4, Audi A6, BMW 320D, Ford Focus, Mercedes-Benz E 220 CDI, Opel Astra and Toyota Avensis.

We should note, however, that the measurement of the exhaust emissions, the $\lambda$ coefficient and the opacity under the testing conditions of an inspection stations do not reflect the on-road conditions, particularly for high engine loads.

The number of the tested vehicles is not large (number of vehicle makes and models of the selected age groups). In the research the results were accompanied by the names of the vehicles but it does not constitute a basis for evaluation of the whole model group of a given vehicle make.

In the case of exhaust opacity level we can see a growth in coefficient $\mathrm{k}$ to the disadvantage of older vehicles (Fig. 5). In vehicle from group III the average value of the smoke level is almost three times higher than in group I. There is a visible correlation between vehicle age and opacity level, similarly to the emission of $\mathrm{CO}$ for gasoline engines.

Paper reviewed/Artykut recenzowany pojazdach, które nie przekroczyły siedmioletniego okresu eksploatacji: Honda Jazz, Hyundai Accent, Mitsubishi Lancer, Opel Corsa i dwie Toyoty Yaris. Wyjątkiem był jeszcze prawie dziewięcioletni Mitsubishi Lancer.

Pomiar zadymienia spalin wykonano w 50 pojazdach. Nie wyodrębniono pojazdów przekraczających dopuszczalny poziom zadymienia spalin. Najniższy poziom stwierdzono w pojazdach, które nie przekroczyły jeszcze sześcioletniego okresu eksploatacji: Audi A4, Audi A6, BMW 320D, Ford Focus, Mercedes-Benz E 220 CDI, Opel Astra i Toyota Avensis.

Należy jednak pamiętać, że pomiar poziomu zanieczyszczeń gazowych spalin, współczynnika $\lambda$ i zadymienia spalin w warunkach SKP nie odzwierciedla warunków drogowych, szczególnie dla dużych obciążeń.

Dodatkowo liczba badanych samochodów jest niewielka, jak na liczbę marek, modeli wyodrębnionych grup wiekowych, dlatego w badaniach wyniki poparto nazwami własnymi pojazdów, co nie jest podstawą do oceny całej grupy modelowej danej marki.

\section{Nomenclature/Skróty i oznaczenia}

$\overline{\mathrm{x}}$ - average value/wartość średnia

$\mathrm{x}_{1}, \mathrm{x}_{2} \ldots \mathrm{x}_{\mathrm{n}}$ - individual sample values/poszczególne wartości próbek

$\mathrm{s}_{\mathrm{b}}$ - standard error/btąd standardowy

$\mathrm{n}$ - number of samples/liczba próbek

$\mathrm{x}_{\mathrm{i}}$ - sample value/wartość próbki

$\mathrm{M}-$ median/mediana

$\mathrm{s}_{\mathrm{o}}$ - standard deviation/odchylenie standardowe

$\mathrm{s}^{2}$ - sample variance/wariancja próbki

$\mathrm{K}$ - kurtosis/kurtoza

$\mathrm{A}_{\mathrm{d}}$ - bias/skośność

\section{Bibliography/Literatura}

[1] Czajka R., Dziedziak P., Gołaszewski M., Radzimirski S., Sowiński A., Taubert S., Traczyk S., Żółtkowski A.: Badania techniczne pojazdów w świetle obowiązujących przepisów - 2007, Instytut Transportu Samochodowego w Warszawie 2007.

[2] Lindstedt P.: Praktyczna diagnostyka maszyn i jej teoretyczne podstawy, Warszawa 2002.

[3] Merkisz J., Mazurek S.: Pokładowe systemy diagnostyczne pojazdów samochodowych, Warszawa 2002.

[4] Rozporządzenie Ministra Infrastruktury z dnia 18 września 2009 r. w sprawie zakresu i sposobu przeprowadzania badań technicznych pojazdów oraz wzorów dokumentów stosowanych przy tych badaniach (Dz. U. z 2009 r., nr 155, poz.1232).

[5] Rozporządzenie Ministra Infrastruktury z dnia 30 grudnia 2003 r. w sprawie homologacji pojazdów samochodowych i przyczep (Dz. U. z 2004 r., nr 5, poz. 30).

Dariusz Szpica, DEng. - doctor in the Faculty of Mechanical Engineering at Bialystok University of Technology.

Dr inż. Dariusz Szpica - adiunkt na Wydziale Mechanicznym Politechniki Białostockiej. email:dszpica@pb.edu.pl
[6] Rozporządzenie Ministra Infrastruktury z dnia 30 lipca 2010 r. zmieniające rozporządzenie w sprawie szczegółowych wymagań w stosunku do diagnostów (Dz. U. z 2010 r., nr 140, poz. 946).

[7] Rozporządzenie Ministra Infrastruktury z dnia 31 grudnia 2002 r. w sprawie warunków technicznych pojazdów oraz zakresu ich niezbędnego wyposażenia (Dz. U. z 2003 r., nr 32, poz. 262 z późniejszymi zmianami).

[8] Rozporządzenie Ministra Infrastruktury z dnia 4 listopada 2004 r. w sprawie szczegółowych wymagań w stosunku do diagnostów (Dz. U. z 2004 r., nr 246, poz. 2469).

[9] Rozporządzenie Ministra Transportu i Budownictwa z dnia 10 lutego 2006 r. w sprawie szczegółowych wymagań w stosunku do stacji przeprowadzających badania techniczne pojazdów (Dz. U. z 2006 r., nr 40, poz. 275).

[10] Rychter M.: Materiały szkoleniowe OBD II/EOBD, Instytut Transportu Samochodowego w Warszawie 2009.

[11] Sobczyk M.: Statystyka, Warszawa 1997.

[12] Ustawa z dnia 20 czerwca 1997 r. - Prawo o ruchu drogowym (Dz. U. z 2005 r., poz. 908 z późniejszymi zmianami).

Sławomir Milewski, Eng. - graduate branch Educational Center in Suwalki, Bialystok University of Technology.

Inż. Stawomir Milewski-absolwent Zamiejscowego Ośrodka Dydaktycznego Politechniki Bialostockiej w Suwatkach.

email: slawek.milewski9@gmail.com 